\title{
Prediction equations for energy values of animal meals obtained using meta-analysis
}

\author{
Camilla Roana Costa de Oliveira ${ }^{1}$ (iD), Carlos Bôa-Viagem Rabello ${ }^{1^{*}}$ (iD), Janete Gouveia de \\ Souza $^{2}$ iD, Guilherme Rodrigues do Nascimento ${ }^{3}$ iD, Elainy Cristina Lopes ${ }^{1}$ iD, Almir Ferreira \\ da Silva ${ }^{1}$ (iD, Jaqueline de Cássia Ramos da Silva ${ }^{1}$ (iD, Gabriel Miranda Macambira ${ }^{1}$ iD
}

\footnotetext{
${ }^{1}$ Universidade Federal Rural de Pernambuco, Departamento de Zootecnia, Recife, PE, Brasil.

${ }^{2}$ Universidade Federal do Rio Grande do Norte, Unidade Acadêmica Especializada em Ciências Agrárias, Macaiba, RN, Brasil.

${ }^{3}$ Instituto Federal de Educação, Ciência e Tecnologia Baiano, Departamento de Zootecnia, Santa Inês, BA, Brasil.
}

\begin{abstract}
The objective of this study was to determine prediction equations to estimate the nitrogen-corrected apparent metabolizable energy (AMEn) values of animal meals used in broiler diets through meta-analysis. A bibliographic review was undertaken with studies conducted in Brazil from 2000 to 2016 to catalogue information on AMEn values and the following chemical elements in the composition of the feedstuffs: crude protein (CP), ether extract (EE), gross energy (GE), mineral matter $(\mathrm{MM})$, calcium $(\mathrm{Ca})$, and phosphorus $(\mathrm{P})$. Groups were also catalogued and formed according to sex and age of birds. Chemical correlations were analyzed, and a multiple linear regression model with the stepwise procedure was used to examine the association between the variables, which were included in the equation as a function of their importance. High and significant correlation coefficients between the independent (GE, MM, CP, EE, Ca, and P) and dependent variable (AMEn) contribute to the understanding of variations in the energy values of these feedstuffs. According to the coefficients of determination, the best equations to estimate AMEn of poultry offal meal and meat and bone meal are AMEn $=6139-45.5 \mathrm{CP}$ $+0.356 \mathrm{GE}-123.5 \mathrm{MM}\left(\mathrm{R}^{2}=0.8302\right)$ and $\mathrm{AMEn}=2267+19.9 \mathrm{CP}+67.9 \mathrm{EE}-44.4 \mathrm{MM}\left(\mathrm{R}^{2}=0.9021\right)$, respectively.
\end{abstract}

Key Words: AMEn, broiler, meat and bone meal, metabolism, prediction

\section{Introduction}

Slaughterhouse byproducts like poultry offal meal and meat and bone meal are dietary sources of protein and phosphorus that can substitute costly ingredients such as soybean meal and dicalcium phosphate. This replacement also addresses environmental concerns, as it represents a proper destination for the waste generated by slaughterhouses.

The precise knowledge of the chemical composition and of nitrogen-corrected apparent metabolizable energy (AMEn) values of animal meal ingredients is necessary for the formulation of nutritionally and economically balanced diets.

However, determining the AMEn content of feedstuffs involves the use of metabolic trials, which are costly and time-demanding. In this regard, feed composition tables

Received: April 20, 2018

Accepted: July 2, 2018

*Corresponding author: carlos.boaviagem@gmail.com

Copyright (C) 2018 Sociedade Brasileira de Zootecnia. This is an Open Access article distributed under the terms of the Creative Commons Attribution License (http://creativecommons.org/licenses/by/4.0/), which permits unrestricted use, distribution, and reproduction in any medium, provided the original work is properly cited. are commonly consulted to obtain the energy values of the ingredients used in diets with greater practicality. Nevertheless, several factors can affect the values in those tables, e.g., the chemical composition of those feedstuffs, the age of birds, and the methodology applied to determine the energy value.

A rapid way to determine the metabolizable energy value is through prediction equations developed as a function of the chemical composition of feedstuffs, which is easily and quickly obtained in most cases. Many studies can be found in the literature establishing prediction equations for the energy values of a number of ingredients (NRC, 1994; Nascimento et al., 2009; Rostagno et al., 2017). However, the obtained results are only applicable to a group of feedstuffs, since one experiment alone reflects only the experimental conditions in which it was developed (Polycarpo et al., 2017).

Therefore, information originating from data collected under different conditions should be merged to generate more consistent results. A technique employed to integrate the quantitative knowledge of multiple studies is metaanalysis, which is based on the synthesis of data from several published studies and on the construction of a statistical model that better explains the observations, generating 
new results (St-Pierre, 2001; Lovatto et al., 2007). Metaanalysis can produce more-accurate prediction equations to calculate the AMEn values of feedstuffs.

The objective of this study was to develop equations to predict the AMEn content of poultry offal meal (POM) and meat and bone meal (MBM) through a meta-analysis of information on the chemical composition of these ingredients obtained by various authors and published in scientific papers.

\section{Material and Methods}

The database was developed from scientific papers published from 2000 to 2016 involving experiments conducted in Brazil, under the guidelines on the use of live animals for research purposes. All selected experiments were aimed at evaluating the chemical composition and AMEn of POM and MBM.

The scientific article search included studies published in journals in the following digital databases: Scielo, CAPES Journals, Scopus, Web of Science, and Google Scholar. This spectrum of mechanisms prevents a possible polarization in terms of articles found in only one database and broadens the search limits.

Once identified, the articles were evaluated critically as to their quality and relevance for the objectives of the meta-analysis. During this stage, the information contained in each selected study was evaluated, including factors pertaining to the experimental project, treatments, studied parameters, methodology of chemical analyses, and data analysis.

The information obtained from the bibliographic review was tabulated according to feedstuff, sex, methodology of the metabolism trial, and age of the animal used in the experiments. The chemical and energy compositions of the feedstuffs, which included the variables crude protein (CP), ether extract (EE), gross energy (GE), mineral matter $(\mathrm{MM})$, calcium $(\mathrm{Ca})$, and phosphorus $(\mathrm{P})$, were tabulated on the basis of the dry matter, which was adjusted at $920 \mathrm{~g} \mathrm{~kg}^{-1}$, following Dale et al. (1993), to nullify the effects of the different moisture contents of the meals.

The database occupied a worksheet with 57 lines, representing the treatments, and 30 columns, representing the exploratory variables, containing 22 articles published between 2000 and early 2016 . The studies included in the database amounted to 6,299 broilers, whose average initial age was 16 days (ranging from 1 to 41 days) and average final age was 25 days (ranging from 7 to 50 days). Most of the studies (57\%) used male broilers, $7 \%$ used females, and $36 \%$ involved mixed batches. The total excreta collection methodology was adopted in $86 \%$ of the articles, and the forced-feeding method with roosters was used in $14 \%$ of them. The level of $20 \%$ inclusion of the test feedstuff in control diet was indicated by most authors, in $40 \%$ of the papers.

The methodology used for coding the data, forming the groups, and weighting followed the proposals described by Lovatto et al. (2007) and Sauvant et al. (2008), considering the effects that influence the energy value of the feedstuffs directly, which do not alter the chemical composition, and which cause variability in the energy value of the feedstuffs, e.g., age and sex of the experimental animals.

Each article was coded to facilitate their identification in the database, with numbers used to form homogeneous groups with common traits to be included in statistical models as sources of variation. Codes were assigned to each effect, and groups were then formed. For the effect of sex, the codes 1, 2, and 3 were assigned to males, females, and mixed batches, respectively. For age, three codes were assigned: 1 for the pre-starter phase, 2 for the starter phase, and 3 for the grower phase. Therefore, the code of effects was $3 \times 3$, with a total maximum of nine groups, which were subjected to analysis of weighted least squares. This weighting factor determines the existing variance for the dependent variable of the multiple linear regression model within each group; in this case, the AMEn of the feedstuffs used.

Assumptions of normal distribution and homoscedasticity of the data were checked, and then a descriptive analysis was carried out (Triola, 1999) to obtain the profile of the dataset based on the central-tendency and dispersion measures and observe the biological coherence of the data.

Pearson's correlation coefficient was used to measure the intensity of the linear correlation between AMEn and the other quantitative variables. Next, the data were subjected to multiple linear regression analysis employing the Stepwise method of indirect elimination, following Nunes et al. (2001) and Nascimento et al. (2011). The dependent variable was AMEn, whereas the independent variables were the $\mathrm{CP}, \mathrm{EE}, \mathrm{GE}, \mathrm{MM}, \mathrm{Ca}$, and $\mathrm{P}$ contents.

Statistical analyses were performed using SAS statistical software (Statistical Analyses System, version 9.0), considering a significance level equal to or lower than 0.05 .

\section{Results}

The average crude protein content in the samples of POM (634.6 $\mathrm{g} \mathrm{kg}^{-1}$ ) (Table 1) showed a visible variability in mineral content, in which the $\mathrm{MM}, \mathrm{Ca}$, and $\mathrm{P}$ percentages had the highest coefficients of variation: 25.73, 24.56, and 
$28.02 \%$, respectively. The coefficient of variation for GE was $16.46 \%$, while that of AMEn was $22.17 \%$. Ether extract ranged from 101.4 to $201.8 \mathrm{~g} \mathrm{~kg}^{-1}$.

For MBM (Table 2), the average CP content was $433.6 \mathrm{~g} \mathrm{~kg}^{-1}$, ranging from 349.9 to $563.0 \mathrm{~g} \mathrm{~kg}^{-1}$, with a coefficient of variation (CV) of $16.23 \%$. The components that most varied were MM, Ca, and $\mathrm{P}$, which averaged 19.35, 28.77 , and $22.92 \%$, respectively. Gross energy ranged from 3001 to $4668 \mathrm{kcal} \mathrm{kg}^{-1}$, with a CV of $15.51 \%$, whereas the CV of AMEn was $28.47 \%$.

In the analysis of the correlations in POM (Table 3), CP was positively correlated $(\mathrm{P}<0.05)$ with $\mathrm{GE}$, but negatively with MM. A positive correlation was found between AMEn and $\mathrm{CP}$ and GE, whereas AMEn was negatively correlated with MM.

The analysis of the chemical components of MBM (Table 4) shows that the CP level is positively correlated with GE and establishes a high negative correlation with MM, $\mathrm{Ca}$, and P. The AMEn in this feedstuff is highly correlated with $\mathrm{CP}$ and GE and negatively with $\mathrm{MM}, \mathrm{Ca}$, and $\mathrm{P}$.

Using the information on chemical composition and the AMEn values obtained in the meta-analysis of the data, four prediction equations were generated for the AMEn of the animal meal (Table 5).

Table 1 - Descriptive statistics of the database with 32 samples (n) of poultry offal meal used in the meta-analysis ${ }^{1}$

\begin{tabular}{|c|c|c|c|c|c|c|c|}
\hline Variable & $\mathrm{CP}\left(\mathrm{g} \mathrm{kg}^{-1}\right)$ & $\mathrm{EE}\left(\mathrm{g} \mathrm{kg}^{-1}\right)$ & GE $\left(\mathrm{kcal} \mathrm{kg}^{-1}\right)$ & $\mathrm{MM}\left(\mathrm{g} \mathrm{kg}^{-1}\right)$ & $\mathrm{Ca}\left(\mathrm{g} \mathrm{kg}^{-1}\right)$ & $\mathrm{P}\left(\mathrm{g} \mathrm{kg}^{-1}\right)$ & $\operatorname{AMEn}\left(\mathrm{kcal} \mathrm{kg}^{-1}\right)$ \\
\hline Minimum & 467.8 & 101.4 & 3784 & 32.8 & 28.3 & 16.5 & 2384 \\
\hline Maximum & 685.2 & 201.8 & 5622 & 210.7 & 61.9 & 39.2 & 4268 \\
\hline Average & 634.6 & 157.8 & 5205 & 148.4 & 47.9 & 24.8 & 3330 \\
\hline SEM & 1.04 & 0.48 & 107 & 0.76 & 0.24 & 0.13 & 90.4 \\
\hline SD & 5.61 & 6.46 & 912 & 6.82 & 7.17 & 4.69 & 678 \\
\hline CV\% & 10.85 & 15.59 & 16.46 & 25.73 & 24.56 & 28.02 & 22.17 \\
\hline
\end{tabular}

CP - crude protein; EE - ether extract; GE - gross energy; MM - mineral matter; AMEn - nitrogen-corrected apparent metabolizable energy; SEM - standard error of the mean; $\mathrm{SD}$ - standard deviation; CV - coefficient of variation.

${ }^{1}$ Values adjusted for $920 \mathrm{~g} \mathrm{~kg}^{-1}$ of dry matter.

Table 2 - Descriptive statistics of the database with 25 samples (n) of meat and bone meal used in the meta-analysis ${ }^{1}$

\begin{tabular}{|c|c|c|c|c|c|c|c|}
\hline Variable & $\mathrm{CP}\left(\mathrm{g} \mathrm{kg}^{-1}\right)$ & $\mathrm{EE}\left(\mathrm{g} \mathrm{kg}^{-1}\right)$ & $\mathrm{GE}\left(\mathrm{kcal} \mathrm{kg}^{-1}\right)$ & $\mathrm{MM}\left(\mathrm{g} \mathrm{kg}^{-1}\right)$ & $\mathrm{Ca}\left(\mathrm{g} \mathrm{kg}^{-1}\right)$ & $\mathrm{P}\left(\mathrm{g} \mathrm{kg}^{-1}\right)$ & $\operatorname{AMEn}\left(\mathrm{kcal} \mathrm{kg}^{-1}\right)$ \\
\hline Minimum & 349.9 & 98.7 & 3001 & 237.7 & 69.7 & 41.5 & 1183 \\
\hline Maximum & 563.0 & 168.3 & 4668 & 498.9 & 177.6 & 87.1 & 2829 \\
\hline Average & 433.6 & 123.4 & 3439 & 392.3 & 132.0 & 68.9 & 2251 \\
\hline SEM & 1.22 & 0.371 & 113 & 1.62 & 0.89 & 0.37 & 106 \\
\hline SD & 5.73 & 1.73 & 505 & 7.59 & 3.80 & 1.57 & 499 \\
\hline $\mathrm{CV} \%$ & 16.23 & 14.07 & 15.51 & 19.35 & 28.77 & 22.92 & 28.47 \\
\hline
\end{tabular}

CP - crude protein; EE - ether extract; GE - gross energy; MM - mineral matter; AMEn - nitrogen-corrected apparent metabolizable energy; SEM - standard error of the mean; $\mathrm{SD}$ - standard deviation; CV - coefficient of variation.

${ }^{1}$ Values adjusted for $920 \mathrm{~g} \mathrm{~kg}^{-1}$ of dry matter.

Table 3 - Pearson's correlation coefficient between AMEn and chemical components of poultry offal meal ${ }^{1}$

\begin{tabular}{lrrrrrr}
\hline Item & \multicolumn{1}{c}{ CP } & \multicolumn{1}{c}{ EE } & GE & MM & Ca & P \\
\hline EE & 0.144 & & & & & \\
$\mathrm{P}^{*}$ & 0.483 & & & & & \\
$\mathrm{GE}$ & 0.801 & 0.720 & & & & \\
$\mathrm{P}^{*}$ & 0.002 & 0.022 & & & & \\
$\mathrm{MM}$ & -0.548 & -0.150 & -0.404 & & & \\
$\mathrm{P}^{*}$ & 0.005 & 0.505 & 0.086 & & & \\
$\mathrm{Ca}$ & 0.231 & 0.334 & 0.578 & 0.386 & & \\
$\mathrm{P}^{*}$ & 0.278 & 0.218 & 0.009 & 0.076 & & \\
$\mathrm{P}$ & -0.218 & -0.366 & -0.441 & 0.352 & -0.261 & \\
$\mathrm{P}^{*}$ & 0.296 & 0.094 & 0.052 & 0.099 & 0.229 & \\
$\mathrm{AMEn}$ & 0.473 & 0.184 & 0.524 & -0.545 & -0.064 & -0.380 \\
$\mathrm{P}^{*}$ & 0.041 & 0.379 & 0.012 & 0.005 & 0.768 & 0.061 \\
\hline
\end{tabular}

AMEn - nitrogen-corrected apparent metabolizable energy; CP - crude protein;

EE - ether extract; GE - gross energy; MM - mineral matter.

${ }^{1}$ Values adjusted for $920 \mathrm{~g} \mathrm{~kg}^{-1}$ of dry matter.

$\mathrm{P}^{*}$ - probability, significant when $\mathrm{P}<0.05$.
Table 4 - Pearson's correlation coefficient between AMEn and chemical components of meat and bone meal ${ }^{1}$

\begin{tabular}{lrrrrrr}
\hline Item & \multicolumn{1}{c}{ CP } & EE & GE & MM & Ca & P \\
\hline EE & 0.162 & & & & & \\
$\mathrm{P}^{*}$ & 0.472 & & & & & \\
GE & 0.880 & 0.462 & & & & \\
$\mathrm{P}^{*}$ & 0.003 & 0.040 & & & & \\
MM & -0.776 & -0.294 & -0.856 & & & \\
$\mathrm{P}^{*}$ & 0.005 & 0.184 & 0.007 & & & \\
Ca & -0.469 & -0.399 & -0.761 & 0.520 & & \\
$\mathrm{P}^{*}$ & 0.049 & 0.101 & 0.001 & 0.027 & & \\
P & -0.733 & -0.261 & -0.811 & 0.866 & 0.780 & \\
$\mathrm{P}^{*}$ & 0.001 & 0.295 & 0.002 & 0.003 & 0.005 & \\
AMEn & 0.787 & 0.416 & 0.836 & -0.846 & -0.505 & -0.741 \\
$\mathrm{P}^{*}$ & 0.000 & 0.054 & 0.006 & 0.004 & 0.032 & 0.003 \\
\hline
\end{tabular}

AMEn - nitrogen-corrected apparent metabolizable energy; CP - crude protein; EE - ether extract; GE - gross energy; MM - mineral matter;

${ }^{1}$ Values adjusted for $920 \mathrm{~g} \mathrm{~kg}^{-1}$ of dry matter.

$\mathrm{P}^{*}$ - probability, significant when $\mathrm{P}<0.05$. 
Table 5 - Nitrogen-corrected apparent metabolizable energy ( $\mathrm{kcal} \mathrm{kg}^{-1}$ ) prediction equations of animal meal (AM) in function of the chemical composition ${ }^{1}$

\begin{tabular}{|c|c|c|c|c|c|c|c|c|}
\hline $\mathrm{AM}$ & Intercept & $\mathrm{CP}$ & $\mathrm{EE}$ & GE & MM & $\mathrm{Ca}$ & $\mathrm{P}$ & $\mathrm{R}^{2}$ \\
\hline POM & $\begin{array}{l}6139 \\
8375\end{array}$ & $\begin{array}{l}-45.5 \\
-46.1\end{array}$ & & $\begin{array}{c}0.356 \\
0.0951\end{array}$ & $\begin{array}{l}-123.5 \\
-113.0\end{array}$ & & & $\begin{array}{l}0.8302 \\
0.8051\end{array}$ \\
\hline MBM & $\begin{array}{l}2267 \\
3113\end{array}$ & 19.9 & $\begin{array}{l}67.9 \\
69.9\end{array}$ & & $\begin{array}{c}-44.4 \\
-57.00\end{array}$ & & & $\begin{array}{l}0.9021 \\
0.8827\end{array}$ \\
\hline
\end{tabular}

POM - poultry offal meal; MBM - meat and bone meal; CP - crude protein; EE - ether extract; GE - gross energy; MM - mineral matter; $\mathrm{R}^{2}$ - coefficient of determination. ${ }^{1}$ Values adjusted for $920 \mathrm{~g} \mathrm{~kg}^{-1}$ of dry matter.

The most representative variables to predict the AMEn values of POM were CP, GE, and MM. As such, they were those which best explained the metabolizable energy value. The equation that obtained the best coefficient of determination was $\mathrm{AMEn}=6139-45.5 \mathrm{CP}+0.356 \mathrm{GE}-$ 123.5 MM $\left(\mathrm{R}^{2}=0.8302\right)$.

For MBM, the equation that best represented the energy values was AMEn $=2267+19.9 \mathrm{CP}+67.9 \mathrm{EE}-44.4 \mathrm{MM}$ $\left(\mathrm{R}^{2}=0.9021\right)$.

\section{Discussion}

The observed amplitude of values can be considered wide enough for the purposes of this study, ensuring a broad scope for use of the generated equations. This is a desirable feature, suggesting that the database used allows for representative projections of the AMEn values of these feedstuffs for broilers.

The fact that the coefficients of variation of GE and AMEn were different can be explained by differences in the methodologies applied, inclusion levels of the tested feedstuff, poultry line, among other factors. Martosiswoyo and Jensen (1988), Jensen (1991), and Dale (1997) considered that the AMEn values of MBM are routinely underestimated when determined by methodologies in which the MBM level in control diet ranges from 40 to $50 \%$. This is possibly because the elevated $\mathrm{Ca}$ and $\mathrm{P}$ levels provided by the high inclusion of MBM compromised the utilization of the other nutrients. Furthermore, the most adequate level of MBM inclusion in control diet to determine energy values is $20 \%$ (Faria Filho et al., 2002).

For EE, the variation may be linked to how the meal is processed, how it is defatted, and even the environment where it is transported (chutes with water, screw press, or mechanical conveyors) (Silva et al., 2010). Butolo (2002) observed that elevated EE levels can reduce the storage time of MBM by increasing its susceptibility to rancidification.

Different byproduct sources can be included in the production of animal meal for the poultry industry (e.g., feathers, blood, and viscera), which contributes to the variation in nutritional levels between these ingredients. In addition to the proportion of raw material used, the concentrations of AMEn, CP, MM, and EE and the quality and digestibility of the amino acids in POM also depend on processing methods and methods of measuring digestibility (Dale et al., 1993; Cao and Adeola, 2016).

The main variation factor in the production of MBM is the percentage of bones in the mixture. Higher concentrations of bone mean lower percentages of protein and GE and, consequently, higher MM contents. According to Dale (1997), the MM content is in general inversely proportional to the amount of crude protein in MBM.

Meat and bone meals are classified according to their $\mathrm{CP}$ content. According to Rostagno et al. (2017), this fraction may vary from 38 to $63 \%$ (fresh matter basis). The average CP data found in the present study fall within the category of " $43 \%$ " established by Rostagno et al. (2017), which includes meals with CP contents between 40 and $45 \%$.

Results for POM reveal that low levels of these minerals mean a higher metabolizable energy value. These findings agree with Silva et al. (2010), who found that AMEn in poultry viscera meal was positively correlated with $\mathrm{CP}$ and GE and negatively with MM, Ca, and P. Pesti et al. (1986), likewise, reported a high negative correlation between AMEn and the MM and Ca contents and a high positive correlation between AMEn and GE.

The difference in the chemical composition of MBM explains the variation in results found for AMEn, since, according to Eyng et al. (2011), together with the $\mathrm{Ca}$ and sodium ions, the high MM value causes saponification of the fats present in the animal meal, reducing the energy utilization of MBM by the birds. This ultimately leads to a decrease in the energy utilization of the feedstuffs.

Dale (1997), Wang and Parsons (1998), and Shirley and Parsons (2001) found that CP and GE decrease when the concentration of $\mathrm{MM}$ increases, and as the latter component increases, so do the $\mathrm{Ca}$ and $\mathrm{P}$ contents.

As the MM content increases, the concentration of digestible amino acids declines, resulting in decreased digestibility of the meal and a negative effect on the protein efficiency value, which in turn leads to a lower body weight gain of the birds (Shirley and Parsons, 2001).

Karakas et al. (2001) used bovine and swine MBM with different $\mathrm{MM}$ values in the feeding of broilers and observed that there was no significant difference between the MBM of different origins in the determination of AMEn. However, the authors noted that high levels of MM (above $43 \%$ ) at high dietary inclusion levels (above 20\%) reduced AMEn values. 
The high and significant correlation coefficients between the independent variables (GE, MM, CP, EE, Ca, and $\mathrm{P}$ ) and the dependent variable (AMEn) corroborate the literature results and provide a better understanding of the variations in the energy values of these feedstuffs.

Because AMEn is influenced by various factors, the choice of variables that might be part of the AMEn prediction model should respect the highest correlation coefficient that will exert an influence upon AMEn, but the ease of using this equation should also be considered. Additionally, models comprising a large number of variables may become complex, since some chemical analyses, which are not easily available, may often prevent the use of equations (Nascimento et al., 2011).

Equations determined by Rodrigues et al. (2002), composed of four variables in the model, explained $94 \%$ or more of the variation in the AMEn values of the soybased feedstuffs. However, the equation composed of only two variables, EE and GE, explained $93 \%$ of the variations. This proves that the fit of a model with two independent variables can be well-applied in the estimate of AMEn of the feedstuffs.

Dolz and Blas (1992) studied MBM in poultry diets and obtained better predictions when they used two variables ( $\mathrm{CP}$ and $\mathrm{EE}$ ), which accounted for more than $96 \%$ of the total variation in the estimates of AMEn values. However, according to NRC (1994), in the case of MBM, the MM variable is important and should be included in the prediction equation.

Moreover, considering that determining $\mathrm{MM}$ is a practical procedure, it can be applied as an instrument for estimating the chemical composition, since, as stated by Najafabadi et al. (2007), the MM content is a good indicator of the chemical composition of animal-derived meals.

The NRC (1994) suggests an AMEn prediction equation developed by Janssen (1989) for MBM, equal to $33.94 \times$ $\mathrm{DM}-45.77 \times \mathrm{MM}+59.99 \times \mathrm{EE}$. For the prediction of AMEn for POM, the NRC (1994) indicates the equations developed by Pesti et al. (1986): $561-154 \times \mathrm{Ca}-622 \times \mathrm{P}$ and $556-63 \times \mathrm{MM}-506 \times \mathrm{P}$, both with $\mathrm{R}^{2}=0.9300$.

To obtain a single prediction equation to estimate the AMEn values of protein vegetable feedstuffs commonly used in broiler diets, Nascimento et al. (2011) conducted a bibliographic review with Brazilian articles cataloguing information on the AMEn values and chemical composition of ingredients. In their review, the best fitting equation to estimate AMEn of protein feedstuffs was AMEn $=2,707.71$ $+58.63 \mathrm{EE}-16.06 \mathrm{NDF}\left(\mathrm{R}^{2}=0.8100\right)$. Based on these results, the correlations among chemical components, the variability of animal-derived feedstuffs, and the criterion adopted in the choice of mathematical models to determine the energy values of animal-derived meals are critical factors for a successful diet formulation.

\section{Conclusions}

The accuracy of fit of the prediction equation for nitrogen-corrected apparent metabolizable energy values, obtained via meta-analysis, is directly related to the variability in the chemical composition of the feedstuffs. The models indicated as adequate, based on the coefficient of determination, to estimate the nitrogen-corrected apparent metabolizable energy values of poultry offal meal and meat and bone meals are AMEn $=6139-45.5 \mathrm{CP}+$ $0.356 \mathrm{GE}-123.5 \mathrm{MM}\left(\mathrm{R}^{2}=0.8302\right)$ and AMEn $=2267+$ 19.9 CP + 67.9 EE - 44.4 MM $\left(\mathrm{R}^{2}=0.9021\right)$, respectively.

The chemical composition and energy values of animal-derived meals and their interaction can be used as data for the development of equations to predict the nitrogen-corrected apparent metabolizable energy contents of these feedstuffs. Considering the wide use of these ingredients in poultry diets, it is appropriate to determine and validate these equations.

\section{Acknowledgments}

The authors wish to thank the Instituto Nacional de Ciência e Tecnologia (INCT), for supporting this research.

\section{References}

Butolo, J. E. 2002. Qualidade de ingredientes na alimentação animal. Agro Comunicação, Campinas, SP.

Cao, M. H. and Adeola, O. 2016. Energy value of poultry byproduct meal and animal-vegetable oil blend for broiler chickens by the regression method. Poultry Science 95:268-275. https://doi.org/ $10.3382 / \mathrm{ps} / \mathrm{pev} 317$

Dale, N. 1997. Advances in defining the nutritive quality of feed ingredients. Poultry Science 9:66-73.

Dale, N.; Fancher, B.; Zumbado, M. and Villackes, A. 1993. Metabolizable energy content of poultry offal meal. Journal Applied Poultry Research 2:40-42. https://doi.org/10.1093/japr/2.1.40

Dolz, S. and Blas, C. 1992. Metabolizable energy of meat and bone meal from Spanish rendering plants as influenced by level of substitution and method of determination. Poultry Science 71:316-322. https://doi.org/10.3382/ps.0710316

Eyng, C.; Nunes, R. V.; Rostagno, H. C.; Albino, L. F. T.; Nunes, C. G. V. and Bruno, L. D. G. 2011. Composição química, valores energéticos e aminoácidos digestíveis verdadeiros de farinhas de vísceras para aves. Revista Brasileira de Zootecnia 39:779-786. https://doi.org/10.1590/S1516-35982010000400012

Faria Filho, D. E.; Faria D. E.; Junqueira O. M.; Rizzo, M. F.; Araújo, L. F. and Araújo, C. S. S. 2002. Avaliação da farinha de carne e ossos na alimentação de frangos de corte. Revista Brasileira de Ciência Avícola 4:001-009. https://doi.org/10.1590/S1516$635 \times 2002000100005$ 
Janssen, W. M. M. A. 1989. European table of energy values for poultry feedstuffs. 3rd ed. Spelderholt Center for Poultry Research and Information Services, Beekbergen, Netherlands.

Jensen, L. S. 1991. Animal byproducts in the formulations. Industria Avicola 38:28-31.

Karakas, P.; Versteegh, H. A. J.; Van Der Honing, Y.; Kogut, J. and Jongbloed, A.W. 2001. Nutritive value of the meat and bone meals from cattle or pigs in broiler diets. Poultry Science 80:1180-1189. https://doi.org/10.1093/ps/80.8.1180

Lovatto, P. A.; Lehnen, C. R.; Andretta, I.; Carvalho, A. D. and Hauschild, L. 2007. Meta-análise em pesquisas científicas enfoque em metodologias. Revista Brasileira de Zootecnia 36:285-294. https://doi.org/10.1590/S1516-35982007001000026

Martosiswoyo, A. W. and Jensen, L. S. 1988. Available energy in meat and bone meal as measured by different methods. Poultry Science 67:280-293. https://doi.org/10.3382/ps.0670280

Najafabadi, H. J.; Moghaddam, H. N.; Pourreza, J.; Shahroudi, F. E. and Golian, A. 2007. Determination of chemical composition, mineral contents, and protein quality of poultry by-product meal. International Journal of Poultry Science 6:875-882. https://doi.org/10.3923/ijps.2007.875.882

Nascimento, G. A. J.; Rodrigues, P. B.; Freitas, R. T. F.; Allaman, I. B.; Lima, R. R. and Reis Neto, R. V. 2011. Equações de predição para estimar os valores da EMAn de alimentos proteicos para aves utilizando a meta-análise. Revista Brasileira de Zootecnia 40:21722177. https://doi.org/10.1590/S1516-35982011001000016

Nascimento, G. A. J.; Rodrigues, P. B.; Freitas, R. T. F.; Bertechini, A. G.; Lima, R. R. and Pucci, L. E. A. 2009. Equações de predição para estimar os valores energéticos de alimentos concentrados de origem vegetal para aves utilizando a metanálise. Revista Brasileira de Zootecnia 38:1265-1271. https://doi.org/10.1590/ S1516-35982009000700015

NRC - National Research Council. 1994. Nutrient requirements of poultry. 9th ed. The National Academy Press, Washington, DC.

Nunes, R. V.; Rostagno, H. S.; Albino, L. F. T.; Gomes, P. C. and Nascimento, A. H. 2001. Valores de aminoácidos digestíveis verdadeiros e equações de predição dos aminoácidos digestíveis do grão e de subprodutos do trigo para aves. Revista Brasileira de Zootecnia 30:774-784. https://doi.org/10.1590/S151635982001000300024
Pesti, G. M.; Faust, L. O.; Fuller, H. L.; Dale, N. M. and Benoff, F. H. 1986. Nutritive value of poultry by-product meal: 1 . metabolizable energy values as influenced by method of determination and level of substitution. Poultry Science 65:2258-2267.

Polycarpo, G. V.; Andretta, I.; Kipper, M.; Cruz-Polycarpo, V. C.; Dadalt, J. C.; Rodrigues, P. H. M. and Albuquerque, R. 2017. Meta-analytic study of organic acids as alternative performanceenhancing feed additive to antibiotics for broiler chickens. Poultry Science 96:3645-3653. https://doi.org/10.3382/ps/pex 178

Rodrigues, P. B.; Rostagno, H. S.; Albino, L. F. T.; Gomes, P. C.; Nunes, R. V. and Toledo, R. S. 2002. Valores energéticos da soja e subprodutos da soja, determinados com frangos de corte e galos adultos. Revista Brasileira de Zootecnia 31:1771-1782. https://doi.org/10.1590/S1516-35982002000700020

Rostagno, H. S.; Albino, L. F. T.; Hannas, M. I.; Donzele, J. L.; Sakomura, N. K.; Perazzo, F. G.; Saraiva, A.; Teixeira, M. V.; Rodrigues, P. B.; Oliveira, R. F.; Barreto, S. L. T. and Brito, C. O. 2017. Brazilian tables for poultry and swine - Feed composition and nutritional requirements. 4th ed. UFV, Viçosa, MG,

Sauvant, D.; Schmidely, P.; Daudin, J. J. and St-Pierre, N. R. 2008. Meta-analyses of experimental data in animal nutrition. Animal 2:1203-1214. https://doi.org/10.1017/S1751731108002280

Shirley, R. B. and Parsons, C. M. 2001. Effect of ash content on protein quality of meat and bone meal. Poulry Science 80:626-632. https://doi.org/10.1093/ps/80.5.626

Silva, E. P.; Rabello, C. B. V.; Albino, L. F. T.; Ludke, J. V.; Lima, M. B. and Dutra Junior, W. M. 2010. Prediction of metabolizable energy values in poultry offal meal for broiler chickens. Revista Brasileira de Zootecnia 39:2237-2245. https://doi.org/10.1590/ S1516-35982010001000020

St-Pierre, N. R. 2001. Invited review: integrating quantitative findings from multiple studies using mixed model methodology. Journal Dairy Science 84:741-755.

Triola, M. S. 1999. Introdução a estatística. 7.ed. Livros Técnicos e Científicos, Rio de Janeiro, RJ.

Wang, X. and Parsons, C. M. 1998. Effect of raw material source, processing systems, and processing temperatures on amino acid digestibility of meat and bone meals. Poultry Science 77:834-841. https://doi.org/10.1093/ps/77.6.834 